\title{
Strategi Pengembangan Masyarakat Petani Lahan Gambut melalui Program Tanggung Jawab Sosial Perusahaan: Analisis Pendekatan Penghidupan Berkelanjutan
}

\author{
Mukhammad Fatkhullah ${ }^{1}$, Iwed Mulyani², Bambang Imawan ${ }^{3}$
}

\begin{abstract}
Abstrak
Indonesia memiliki kontribusi pada perubahan iklim global melalui lahan gambut yang tersebar dari Sumatra, Kalimantan, hingga Papua. Sayangnya, pengelolaan lahan gambut di Indonesia belum mengindahkan aspek keberlanjutan. Hal ini berkaitan erat dengan kemiskinan dan keterbelakangan masyarakat petani. Penelitian ini berfokus untuk melihat bagaimana strategi pengembangan masyarakat petani lahan gambut dengan menggunakan pendekatan penghidupan berkelanjutan melalui program Desa Wisata Gambut Sejahtera (DEWIGATRA). Hasilnya, DEWIGATRA berhasil menyejahterakan kelompok petani lahan gambut melalui dua cara. Pertama, mitigasi kebencanaan melalui peningkatan kualitas modal social, human dan physical. Hal ini diwujudkan dengan melakukan reintegrasi kelompok Masyarakat Peduli Api, pelaksanaan pelatihan mitigasi bencana karhutla, serta pengadaan sarana dan prasarana berupa alat pemadam dan embung. Kedua, pengembangan modal natural dan financial melalui program pemberdayaan. Upaya ini dilakukan dengan mengubah sistem pertanian dengan menghadirkan inovasi $d r i p$ irrigation system.
\end{abstract}

Kata kunci: Pengembangan Masyarakat, Petani Lahan Gambut, Penghidupan Berkelanjutan

\begin{abstract}
Indonesia has an important role in global climate change because of its peatlands that spread from Sumatra, Kalimantan to Papua. Unfortunately, peatland management in Indonesia has not heeded the sustainability aspect. This is closely related to the poverty and backwardness of the farming community. This study aims to determine the development strategy of peatland farming communities with using a sustainable livelihood approach through Desa Wisata Gambut Sejahtera (DEWIGATRA) program. As a result, DEWIGATRA prospered peatland farmer groups in two ways. First, disaster mitigation through improving the quality of social, human and physical capital. This is realized by reintegrating the Fire Care Community group, implementing forest fire disaster mitigation training, as well as providing facilities and infrastructure in the form of fire extinguishers and reservoirs. Second, increasing natural and financial capital through empowerment programs. This effort is carried out by changing the agricultural system by introducing the drip irrigation system innovation.
\end{abstract}

Keywords: Community Development, Peatland Farmer, Sustainable Livelihood

\section{Pendahuluan}

Kemampuan unik dalam menyimpan karbon dua kali lebih banyak dari hutan di seluruh dunia dan empat kali lebih banyak dari yang ada di atmosfer membuat peran lahan gambut menjadi sentral dalam upaya mitigasi dan adaptasi perubahan Iklim, terkhususnya lahan gambut di wilayah tropis (Kolka et al., 2016). Meskipun ekosistem gambut hanya memiliki proporsi 3-5\% di permukaan bumi, jenis lahan ini menyimpan lebih dari 30\% esensi karbon dunia yang tersimpan di dalam tanah (Christophersen, 2016). Meski demikian, esensi karbon dalam tanah gambut bersifat labil karena sangat mudah teremisi dan menimbulkan banyak permasalahan jika terjadi gangguan terhadap kondisi alaminya (Las et al., 2012:19). Pengelolaan lahan tanpa mengedepankan aspek yang keberlanjutan (sustainability) memberikan sumbangsih pada emisi karbon dioksida sebanyak 5\% dari seluruh emisi yang dihasilkan oleh aktivitas manusia.

Setelah Kanada (170 juta ha), Rusia (150 juta ha), dan Amerika Serikat (40 juta ha), Indonesia menjadi negara dengan bentangan hutan gambut terbesar keempat di dunia (Najiyati et

\footnotetext{
${ }^{1}$ PT Kilang Pertamina Internasional (email korespondensi: m.fatkhullah@mail.ugm.ac.id)

${ }^{2}$ PT Kilang Pertamina Internasional (email: iwed.mulyani@yahoo.com)

${ }^{3}$ PT Pertamina (Persero) Tbk. (email: bambang.imawan@pertamina.com)
} 
M. Fatkhullah, Iwed Mulyani, Bambang Imawan - Strategi Pengembangan Masyarakat Petani Lahan Gambut melalui Program Tanggung Jawab Sosial Perusahaan: Analisis Pendekatan Penghidupan Berkelanjutan

al., 2005:8). Oleh karena itu, Indonesia memiliki kontribusi yang signifikan terhadap perubahan iklim (Hergoualc'h et al., 2018), mengingat lahan gambut di wilayah tropis menyimpan karbon yang paling banyak dibanding jenis gambut pada kawasan iklim lain dan $80 \%$ diantaranya telah dikelola, baik oleh pemerintah, swasta, maupun masyarakat setempat (Strack, 2008).

Sayangnya, pengelolaan lahan gambut di Indonesia belum mengindahkan aspek keberlanjutan. Dalam kurun waktu tahun 1990 sampai 2020, tutupan hutan pada lahan gambut telah mengalami penurunan lebih dari $50 \%$, tepatnya dari 77\% menjadi 36\%. Hal tersebut terjadi di Sumatra, Semenanjung Malaysia, dan Kalimantan (Comeau et al., 2013). Hal ini utamanya disebabkan oleh pembukaan lahan dengan cara dibakar. Di Indonesia, insiden pembukaan lahan yang berujung pada kebakaran hebat terjadi antara September hingga Oktober 2015. Sebanyak 11,3 juta ton karbon dioksida diperkirakan telah terlepas setiap harinya karena kebakaran ini (Huijnen et al., 2016), dimana muatan karbon yang jumlahnya lebih besar dari emisi karbon harian seluruh Uni Eropa dalam jangka waktu yang sama (Ramsay, 2016). Dampak yang ditimbulkan tentunya tidak sebatas pada masalah kesehatan serius seperti Infeksi Saluran Pernapasan Atas (ISPA), namun juga bertanggung jawab terhadap perubahan iklim global (Burrows, 2016).
Upaya untuk meminimalisir emisi karbon dioksida akibat kesalahan dalam pengelolaan lahan gambut merupakan salah satu bentuk perwujudan Sustainable Development Goals (SDGs). Di Indonesia sendiri, inisiatif tersebut ditunjukkan dengan membentuk Badan Restorasi Gambut (BRG). Akan tetapi dalam prosesnya, lembaga ini tidak mungkin menyelesaikan misinya jika hanya berdiri seorang diri. Salah satu pihak yang terlibat aktif dalam upaya tersebut adalah PT Pertamina Refinery Unit II Dumai yang ada di Provinsi Riau. Mengingat bahwa Provinsi Riau merupakan provinsi dengan sebaran lahan gambut terbesar di Indonesia, perusahaan dengan core bisnis pengolahan minyak mentah ini berupaya untuk melestarikan gambut melalui program Desa Wisata Gambut Sejahtera (DEWIGATRA).

Berangkat dari ulasan tersebut, penelitian ini berusaha melihat bagaimana strategi pengembangan masyarakat, khususnya petani lahan gambut pada program DEWIGATRA. Lebih lanjut, fokus dari kajian ini adalah untuk memetakan kesesuaian pelaksanaan program dengan potensi dan risiko yang ada pada masyarakat petani di lahan gambut. Selain fokus utama tersebut, penelitian ini juga berupaya untuk melihat kontribusi program pada peningkatan pendapatan masyarakat, mitigasi bencana, dan efisiensi pertanian di lahan gambut. Penelitian ini menjadi menarik

Tabel 1.

Sebaran Lahan Gambut di Indonesia

\begin{tabular}{|c|c|c|c|c|}
\hline AREA & PROVINSI & LUAS & $\%$ & TOTAL \\
\hline \multirow{10}{*}{ Sumatra } & Aceh & 215,704 & $1.4 \%$ & \multirow{10}{*}{$43.2 \%$} \\
\hline & Sumatra Utara & 261,234 & $1.8 \%$ & \\
\hline & Sumatra Barat & 100,687 & $0.7 \%$ & \\
\hline & Riau & $3,867,413$ & $25.9 \%$ & \\
\hline & Kepulauan Riau & 8,186 & $0.1 \%$ & \\
\hline & Jambi & 621,089 & $4.2 \%$ & \\
\hline & Bengkulu & 8,052 & $0.1 \%$ & \\
\hline & Sumatra Selatan & $1,262,385$ & $8.5 \%$ & \\
\hline & Bangka Belitung & 42,568 & $0.3 \%$ & \\
\hline & Lampung & 49,331 & $0.3 \%$ & \\
\hline \multirow{4}{*}{ Kalimantan } & Kalimantan Barat & $1,680,135$ & $11.3 \%$ & \multirow{4}{*}{$32.1 \%$} \\
\hline & Kalimantan Tengah & $2,659,234$ & $17.8 \%$ & \\
\hline & Kalimantan Selatan & 106,271 & $0.7 \%$ & \\
\hline & Kalimantan Timur & 332,265 & $2.2 \%$ & \\
\hline \multirow{2}{*}{ Papua } & Papua & $2,644,438$ & $17.7 \%$ & \multirow{2}{*}{$24.8 \%$} \\
\hline & Papua Barat & $1,046,483$ & $7.0 \%$ & \\
\hline TOTAL & & $14,905,475$ & $100.0 \%$ & $100.0 \%$ \\
\hline
\end{tabular}

Sumber: Ritung et al. (2011) 
karena kerusakan ekosistem gambut pada umumnya diakibatkan oleh kemiskinan dan keterbelakangan masyarakat yang tinggal di sekitar lahan gambut itu sendiri (Zulkarnaini \& Lubis, 2018). Penelitian ini menjadi penting karena komunitas petani lahan gambut memiliki kontribusi yang besar, baik bagi pelestarian ekosistem gambut, maupun perusakannya (Najiyati et al., 2005:37-50).

\section{Kerangka Teori}

Livelihood atau penghidupan didefinisikan sebagai kepemilikan sumber daya, kemampuan mengelola, dan berbagai kegiatan lainnya yang dibutuhkan oleh masyarakat untuk menjalani kehidupannya. Penghidupan akan berkelanjutan jika aspek-aspek dalam suatu masyarakat memampukan mereka untuk bisa bertahan dan memulihkan diri dari berbagai tekanan dan guncangan, serta secara terus menerus meningkatkan kualitas sumber daya dan pengelolaannya (asset) untuk kesejahteraan sekarang maupun di masa depan tanpa menurunkan nilai sumber daya alam yang ada (Chambers \& Conway, 1992:296).

Kerangka kerja penghidupan berkelanjutan mengidentifikasi lima aset atau modal utama yang kemudian disebut sebagai Pentagonal Aset (The Asset of Pentagon), di mana penghidupan dibangun. Kategori yang dapat menggambarkan hubungan antar aset ini kemudian divisualisasikan dalam bentuk pentagon (De Stagé et al., 2002:97-110).

\section{Gambar 1}

Diagram Pentagonal Aset pada Pendekatan Penghidupan Berkelanjutan

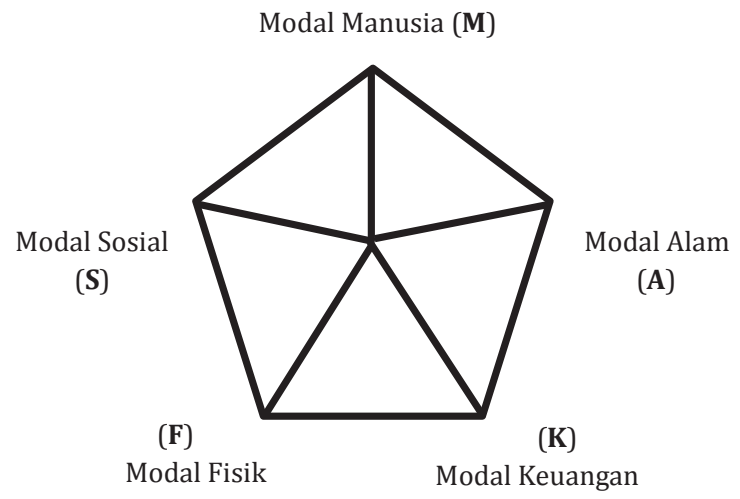

Sumber: Kollmair, 2002:5-7

Adapun penjelasan dari lima aset tersebut adalah sebagai berikut:
1. Modal manusia (human capital), yakni segala bentuk potensi individu dalam suatu masyarakat seperti halnya kondisi kesehatan, tingkat pendidikan, wawasan dan keterampilan teknis, profesionalitas kerja, serta kemampuan untuk beradaptasi;

2. Modal alam (natural capital), yakni terwujud dalam kepemilikan sumber daya alam seperti tanah dan hak produksinya, sumber air yang bagus dan dapat diandalkan untuk berbagai kegiatan domestik, keanekaragaman hayati yang produktif, serta sumber daya lain yang berkaitan erat dengan lingkungan;

3. Modal fisik (physical capital), yakni kepemilikan benda-benda yang dapat menunjang kehidupan seperti teknologi dan alat-alat produksi, aksesibilitas dan transportasi, gedung kesehatan dan fasilitas pendidikan, sarana dan prasarana kebersihan, hingga jaringan radio dan komunikasi lainnya;

4. Modal finansial (financial capital), yakni berbagai sumber atau akses terhadap sumber keuangan seperti diversifikasi pendapatan, keberadaan tabungan, dana pensiun, bentuk investasi, baik tradisional maupun modern, serta akses terhadap kredit atau pinjaman;

5. Modal sosial (social capital), yakni keeratan hubungan yang terjalin antar individu dalam masyarakat dan terlembagakan, baik secara formal seperti pada forum RT, kelompok tani, kelompok kerja, maupun informal seperti kelompok arisan.

Kerangka kerja penghidupan berkelanjutan menempatkan penduduk sebagai pusat yang saling berpengaruh dan berkaitan erat dengan aset yang lain. Dalam konteks ini, akses yang dimiliki penduduk dalam menggunakan sumber daya dan aset mata pencaharian menjadi pusat perhatian yang sentral. Akan tetapi, dimensi kerentanan memiliki porsinya sendiri dalam kerangka kerja penghidupan berkelanjutan. Kerentanan dapat menjadi penghalang atau batu sandungan bagi masyarakat untuk mengoptimalkan aset atau berbagai jenis modal yang mereka miliki. Selain kerentanan, akses terhadap aset penghidupan juga dipengaruhi oleh lingkungan politik, sosial, dan kelembagaan. Berbagai dimensi (aset penghidupan, kerentanan, dan akses masyarakat) kemudian menjadi satu kesatuan 
M. Fatkhullah, Iwed Mulyani, Bambang Imawan - Strategi Pengembangan Masyarakat Petani Lahan Gambut melalui Program Tanggung Jawab Sosial Perusahaan: Analisis Pendekatan Penghidupan Berkelanjutan

Gambar 2

Kerangka Kerja Penghidupan Berkelanjutan

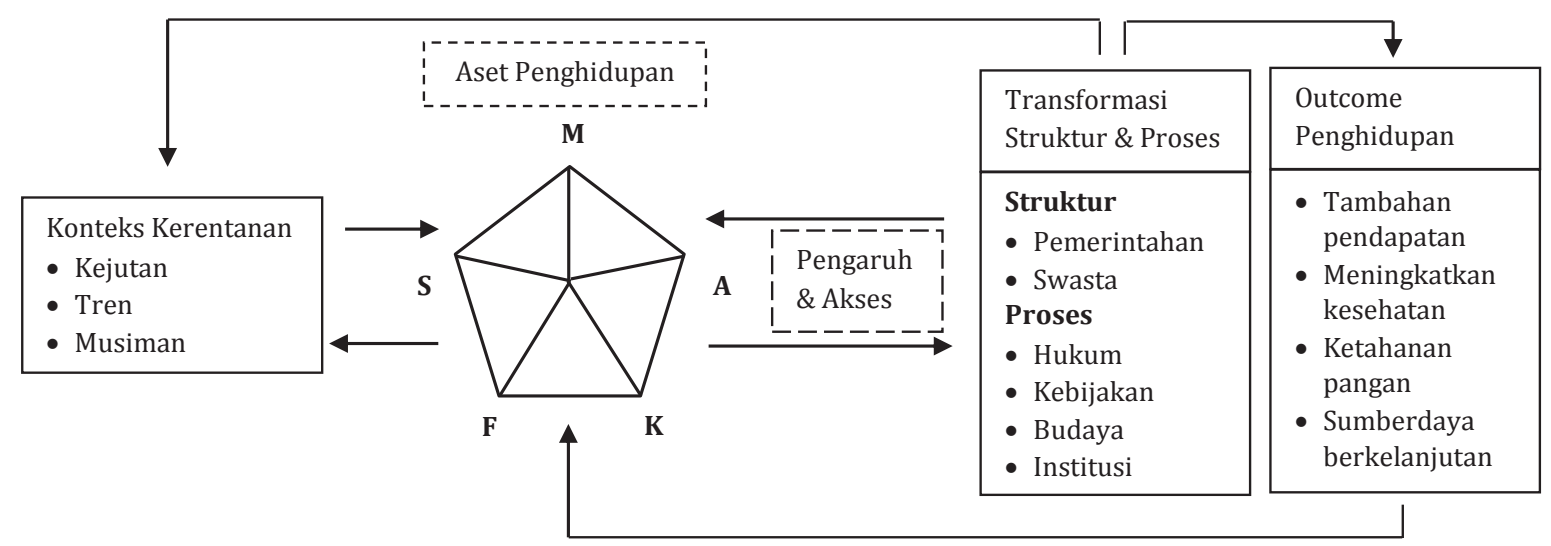

Sumber: Kollmair, 2002:4

yang saling mempengaruhi. Pada gilirannya, hal-hal tersebut mempengaruhi cara masyarakat untuk menggunakan dan mengombinasikan aset mereka untuk mencapai tujuan.

Pada pengertian ini, penghidupan berkelanjutan dapat digunakan sebagai pendekatan untuk melihat gambaran kenyataan yang utuh terkait realitas penghidupan komunitas yang diamati. Hal ini dikarenakan konsep keberlanjutan sendiri memiliki banyak dimensi, antara lain: penghidupannya bersifat lentur dalam menghadapi tekanan dari luar, tidak bergantung pada bantuan dari luar, mempertahankan produktivitas jangka panjang, dan tidak merugikan sumber atau pilihan bagi orang lain. Banyaknya dimensi dalam penghidupan berkelanjutan membuat pendekatan ini tidak hanya bertumpu pada sumber daya yang tunggal, melainkan multidimensional sebagai suatu unsur pendukung kehidupan masyarakat.

\section{Metode Penelitian}

Penelitian ini menggunakan metode kualitatif-deskriptif, dilaksanakan di Kelurahan Tanjung Palas, Kecamatan Dumai Timur, Kota Dumai, serta dilakukan secara partisipatif dengan melakukan pendampingan pada setiap proses atau tahapan kegiatan dari bulan April hingga Juni 2021. Adapun pendekatan yang digunakan dalam penelitian ini adalah pendekatan penghidupan berkelanjutan, sehingga unit analisis dari penelitian ini adalah aset-aset penghidupan, risiko dan konteks kerentanan, serta kebijakan yang diterapkan pada komunitas petani di lahan gambut.

Adapun informan yang dipilih dalam penelitian ini ditentukan melalui teknik purposive, dengan mempertimbangkan kapabilitas tiap informan untuk menjawab pertanyaan. Informan yang dimaksudkan adalah Unit Manager CSR dan Community Development Officer PT Pertamina RU II Dumai, Lurah Tanjung Palas, Pendamping dari Dinas Pertanian, Ketua Kelompok Tani Paman Jaya Mandiri beserta anggota kelompoknya, penerima manfaat dan local hero dari komunitas pertanian lahan gambut.

Data penelitian diperoleh melalui wawancara, observasi, dan dokumentasi. Wawancara didasarkan pada pedoman wawancara, sedangkan observasi dilakukan secara langsung untuk melihat kondisi nyata keseharian komunitas petani lahan gambut di Kelurahan Tanjung Palas. Sementara itu, studi dokumentasi dilakukan bertujuan untuk melengkapi data penunjang seperti letak administrasi, potensi, risiko, serta kebijakankebijakan terkait pertanian lahan gambut. Salah satu sumber dokumentasi adalah penelitian terdahulu, pemetaan sosial, serta peraturan daerah tentang tata ruang kota dan rencana jangka panjang pembangunan daerah. Data yang telah dihimpun kemudian direduksi dan disajikan untuk kemudian ditarik kesimpulan (Moeloeng, 2010:324328). Adapun pemeriksaaan keabsahan data dilakukan dengan metode triangulasi, diskusi serta memperpanjang pelaksanaan penelitian. 


\section{Hasil}

Aset Penghidupan pada Pertanian Lahan Gambut

Gambut mulai gencar dibicarakan saat akademisi mulai menyadari bahwa lahan gambut tidak hanya berfungsi sebagai pengatur hidrologi, sarana konservasi keanekaragaman hayati, tempat budidaya, dan sumber energi; namun juga memiliki kontribusi yang besar khususnya terhadap perubahan iklim global karena kemampuan uniknya dalam menyerap dan menyimpan karbon. Dalam kondisi alaminya, lahan gambut memiliki kemampuan untuk menyimpan pasokan air dalam jumlah besar, sehingga dapat difungsikan untuk menyimpan (recharge) dan melepaskan (discharge) debit air tanah, mengendalikan banjir, serta memasok air (Dugan, 1990:96). Dengan kata lain, lahan gambut merupakan waduk alami dengan kapasitas yang luar biasa (Notohadiprawiro, 2006). Keunikan tersebut membuat beberapa macam flora dan fauna hanya dapat hidup dengan baik di lahan gambut, sehingga apabila kelestarian lahan ini terganggu atau bahkan mengalami kerusakan, bisa dipastikan dunia akan kehilangan keanekaragaman hayati berupa flora dan fauna endemik yang hanya bisa tumbuh di lahan gambut tropis.

Di Sumatra sendiri, terdapat lebih dari 300 flora yang tumbuh di ekosistem gambut (Giesen, 1991). Dari sekian banyak tumbuhan khas gambut tropis, beberapa yang memiliki nilai ekonomi tinggi antara lain adalah bungur, jelutung, kempas, meranti, nyatoh, punak, perepat, pulai rawa, ramin dan terentang (Wibisono et al., 2004). Sementara itu, satwa langka yang bisa ditemukan di ekosistem gambut tropis seperti beruang madu, buaya sinyulong, harimau sumatra, mentok rimba, tapir, dan bangau tongtong (Najiyati et al., 2005:5-8).

Keanekaragaman hayati pada lahan gambut inilah yang menjadi sumber plasma nutfah, substansi yang mengatur perilaku kehidupan secara turun temurun, sehingga populasinya mempunyai sifat yang membedakan dari populasi yang lainnya. Perbedaan tersebut dapat dilihat dari bentuk fisik, ketahanan terhadap penyakit, kemampuan yang lebih adaptif terhadap perubahan lingkungan, dan lain-lain (Kurnia, 2014). Dengan kata lain, kelestarian ekosistem gambut merupakan aset penghidupan yang memiliki kegunaan dalam agrobisnis untuk menghasilkan komoditas yang tahan penyakit, produktif, serta adaptif.

Hal ini didukung dengan fleksibilitas lahan gambut yang dapat diolah dan dimanfaatkan sebagai sarana budidaya tanaman, peternakan, bahkan perikanan. Sebagai gambaran, beberapa suku asli Indonesia seperti Dayak, Bugis, Banjar, dan Melayu sudah sejak lama memanfaatkan lahan gambut untuk aktivitas pertaniannya. Hanya saja, mereka mengolah lahan gambut menjadi kawasan budidaya dengan skala yang kecil dan dengan menggunakan teknologi yang masih sangat tradisional (Sutaryo \&

\section{Gambar 3 \\ Peta Sebaran Lahan Gambut di Kota Dumai}

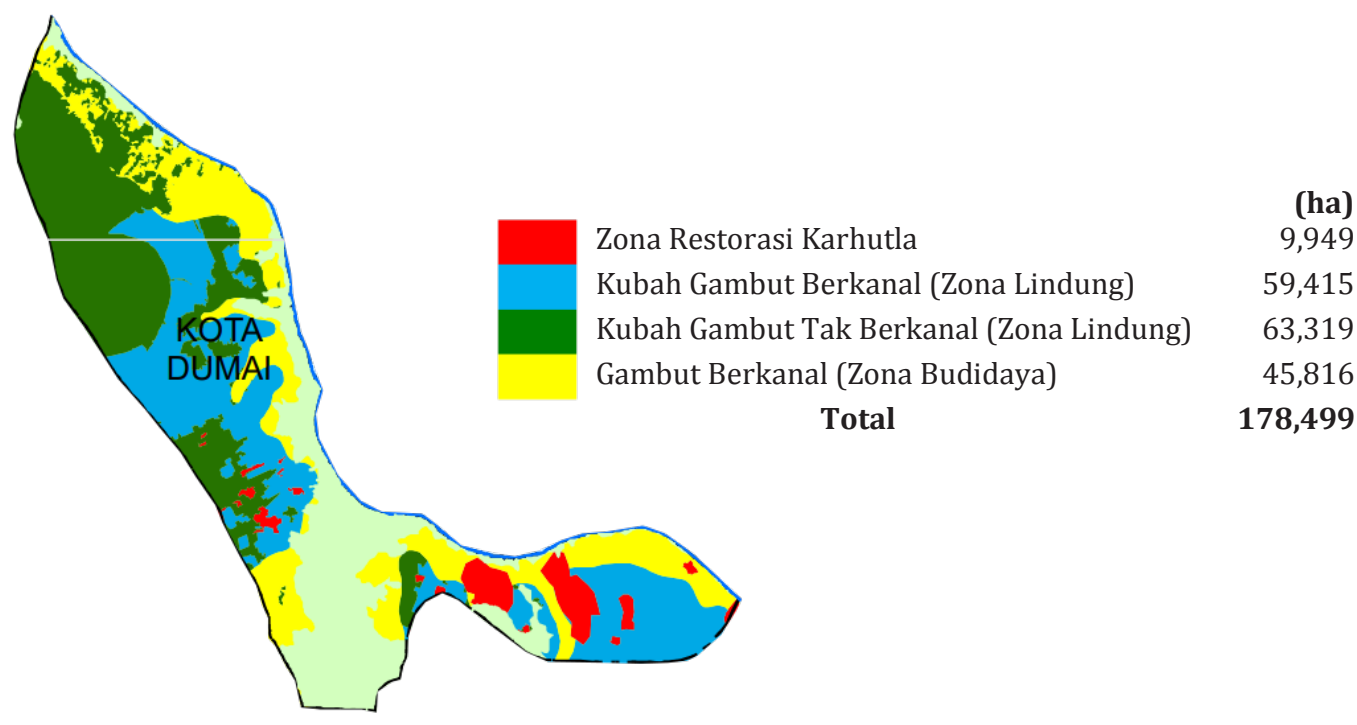

Sumber: Badan Restorasi Gambut, 2017 
M. Fatkhullah, Iwed Mulyani, Bambang Imawan - Strategi Pengembangan Masyarakat Petani Lahan Gambut melalui Program Tanggung Jawab Sosial Perusahaan: Analisis Pendekatan Penghidupan Berkelanjutan

Suryadiputra: 13). Sementara di Dumai sendiri, $25 \%$ lahan gambut yang ada merupakan lahan gambut budidaya yang telah dimanfaatkan oleh petani dan menjadi sumber penghidupan mereka.

\section{Dimensi Risiko dan Konteks Kerentanan pada Pertanian Lahan Gambut}

Ketika pertumbuhan ekonomi meningkat dan penduduk mulai meledak, permintaan terkait kebutuhan komoditas pertanian pun tidak dapat dibendung. Hal ini memberikan implikasi pada perluasan lahan pertanian yang berlangsung secara masif. Sayangnya, alih fungsi hutan gambut sebagai kawasan pertanian kerap mengabaikan daya dukung serta sifat lahan gambut itu sendiri. Hal ini diperparah dengan perencanaan budidaya pertanian yang kurang matang, implementasi tanpa memperhatikan kaidah konservasi lahan, pemanfaatan lahan yang tidak sesuai peruntukannya, serta penerapan teknologi pertanian yang kurang tepat. Pada prosesnya, hal tersebut menyebabkan lahan gambut mengalami kerusakan dan hasil pertanian pun kerap mengalami kegagalan.

Kerusakan yang terjadi beberapa dekade terakhir membuat potensi lahan gambut tidak dapat dimanfaatkan secara optimal. Hal ini terlebih karena belum adanya kesadaran dari masyarakat yang hidup di lahan gambut. Selain penebangan liar, aktivitas industri, pertanian dan perkebunan (khususnya untuk komoditas sawit) memiliki peranan besar terhadap kerusakan ekosistem gambut. Pada pengertian ini, reklamasi dengan sistem drainase yang ada pada perkebunan berskala besar yang umumnya dilakukan secara berlebihan menjadi faktor utama keringnya lahan gambut. Kondisi tersebut diperparah oleh kegiatan pembukaan lahan dengan cara dibakar, yang membuat kerusakan lahan gambut semakin meluas setiap tahunnya.

Jika dibanding dengan ekosistem lain, lahan gambut lebih mudah terbakar karena tingginya bahan organik, sifat kering yang tak balik, daya hantar hidrolik vertikal yang rendah, serta memiliki ruang atau pori dalam lapisannya. Kondisi tersebut juga membuat bencana kebakaran hutan dan lahan (karhutla) di lahan gambut menjadi lebih merugikan dan berbahaya. Pertama, lahan gambut yang terbakar memiliki bara api yang berada di bawah permukaan tanah, sehingga sangat sulit untuk dideteksi dan mudah menjalar tanpa disadari. Hal inilah yang menjadi kendala terbesar bagi upaya pemadaman. Oleh sebab itu, membutuhkan penyemprotan intensif atau air hujan untuk memadamkannya. Kedua, upaya pemulihan hutan gambut yang terbakar sangat sulit untuk dilakukan. Hal ini disebabkan karena lahan gambut merupakan ekosistem yang kompleks dan tak tergantikan. Sifatnya yang menggenang dan asam membuat biaya untuk memulihkannya jauh lebih mahal dibandingkan dengan hutan biasa. Faktor lain yang menyebabkan sulitnya melakukan restorasi pada lahan gambut bekas terbakar adalah banyaknya hambatan. Misalnya saja munculnya genangan, sulitnya aksesibilitas, serta rawan terbakar kembali. Ketiga, apabila lapisan gambut habis karena terbakar dan hanya menyisakan lapisan pasir, maka area tersebut akan berubah menjadi kawasan padang pasir yang gersang. Skenario buruk lain adalah jika di bawah gambut terdapat tanah mineral yang mengandung pirit, maka lapisan itu akan teroksidasi dan berubah menjadi senyawa yang sangat asam. Keempat, sekalipun secara alami lahan gambut berhasil memulihkan diri pasca kebakaran, mereka tidak akan menjadi habitat bagi ekosistem yang sama. Butuh waktu yang cukup lama dan upaya yang terbilang tidak biasa. Terakhir, masifnya kandungan karbon yang terlepas dari lahan gambut pasca terbakar merupakan salah satu penyebab menurunnya kualitas atmosfer bumi (Wibisono et al., 2004).

Penelitian tentang penyebab kebakaran di lahan gambut dan dampak yang ditimbulkan sebenarnya sudah banyak dilakukan, baik oleh Departemen Kehutanan, Wetlands InternationalIndonesia Programme, CIFOR, ICRAF, Perguruan Tinggi, dan Lembaga penelitian lainnya. Umumnya, mereka mengidentifikasi penyebab kebakaran hutan, yang secara ringkas dipicu oleh:

1. Land clearing atau pembersihan lahan dengan cara dibakar, baik untuk usaha pertanian, perkebunan, industri maupun perumahan;

2. Kecerobohan tatkala membuat api di dalam hutan untuk memasak makanan dan minuman;

3. Penangkapan ikan di musim kemarau, khususnya di daerah lebak-lebung (floodplain) yang mengharuskan masyarakat untuk membakar rumput di sekitar kolah agar lebih mudah dalam menangkap ikan, dan; 
4. Konflik lahan antara masyarakat dengan perusahaan Hutan Tanaman Industri, atau pihak pemegang Hak Pengusahaan Hutan.

Berikut di bawah ini gambar 4 yang memperlihatkan hubungan antara penyebab dan dampak yang ditimbulkan oleh kebakaran hutan gambut. Dari gambar tersebut, dapat dilihat bahwa bencana kebakaran pada lahan gambut memiliki dampak yang sangat kompleks. Mulai dari perubahan tata air dan menurunnya kualitas air, pendangkalan dasar sungai dan amblasnya permukaan gambut, terbentuknya tanah sulfat masam yang berujung pada hilangnya keanekaragaman hayati, serta perubahan iklim yang menjadi perhatian banyak pakar dalam beberapa tahun terakhir. Tidak sampai di sana, lahan gambut yang terbakar biasanya meninggalkan sisa berupa tumpukan kayu dan tonggak pohon kering yang siap terbakar kembali.

Meskipun karhutla terjadi karena ulah manusia, namun bukan berarti manusia sepenuhnya mendapatkan keuntungan darinya. Munculnya kabut asap yang menyebabkan penurunan jarak pandang, lumpuhnya aktivitas perekonomian suatu daerah, terganggunya transportasi dan jadwal penerbangan, banyaknya kasus infeksi saluran pernapasan, serta kondisi lain yang berujung pada penurunan kualitas hidup membuktikan bahwa kebakaran hutan dan lahan bukanlah masalah yang bisa dianggap remeh. Akan tetapi, korban yang paling dirugikan masihlah alam itu sendiri. Terancamnya keanekaragaman hayati, terbentuknya tanah sulfat masam, penurunan permukaan tanah, pendangkalan dasar sungai, menurunnya kualitas air, intrusi air laut, kekeringan di musim kemarau dan banjir di musim hujan; semuanya merupakan masalah lingkungan lain yang muncul karena rusaknya lahan gambut.

Selain kebakaran dan kebanjiran, dimensi kerentanan lain yang menghantui masyarakat yang tinggal di lahan gambut adalah kemiskinan. Mata pencaharian masyarakat di kawasan gambut umumnya bertani, memelihara ternak, serta budidaya atau mencari ikan. Sayangnya, pertanian di lahan gambut tidak lebih menguntungkan atau bahkan sangat kurang jika dibandingkan dengan pertanian di lahan mineral. Adapun hal tersebut dikarenakan:

1. Rendahnya kesuburan pada permukaan gambut,

2. Kematangan dan ketebalan gambut yang tidak merata,

3. Masalah degradasi dan penurunan permukaan gambut,

Gambar 4

Faktor Penyebab KARHUTLA dan Dampak yang Menyertainya

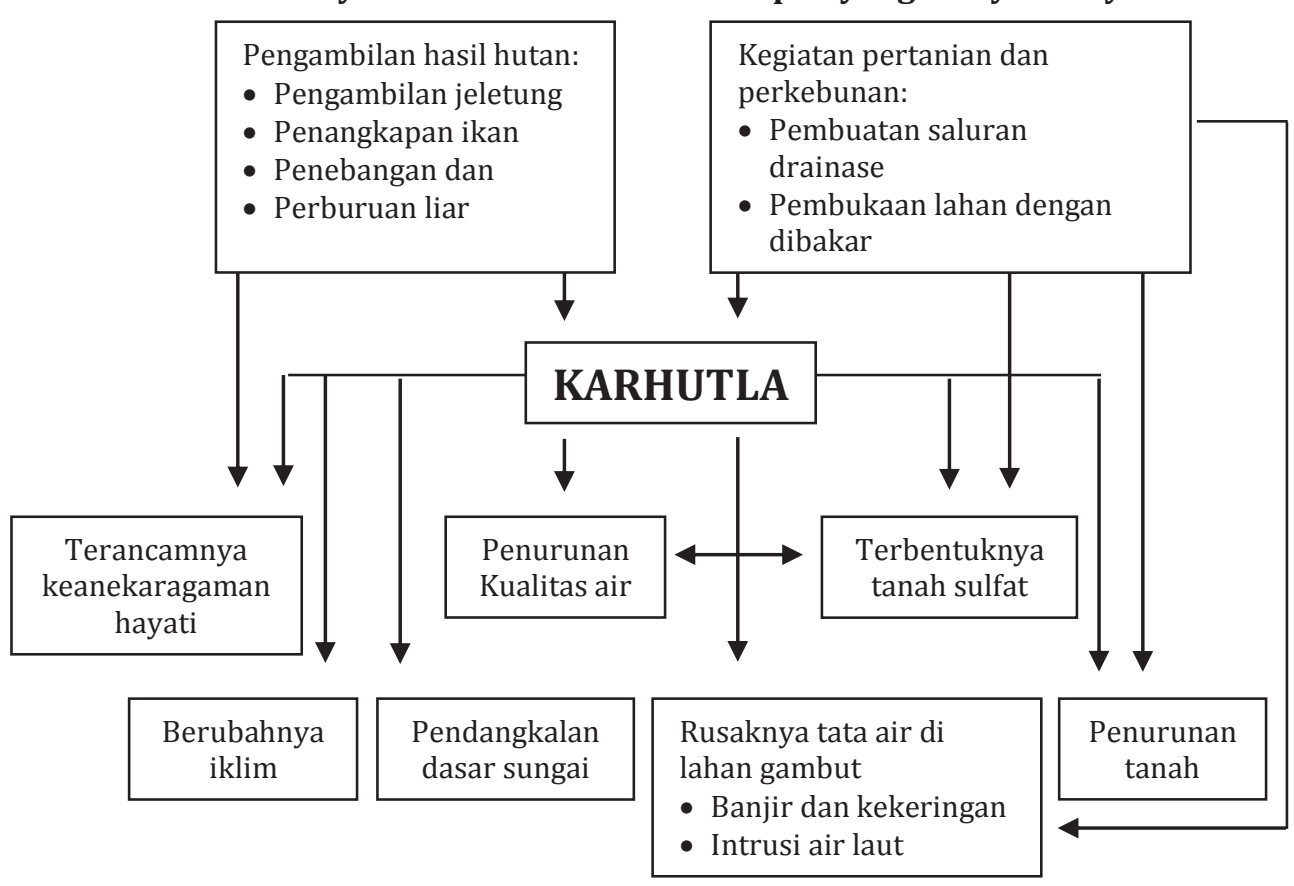

Sumber: Najiyati et al., 2005:12 
M. Fatkhullah, Iwed Mulyani, Bambang Imawan - Strategi Pengembangan Masyarakat Petani Lahan Gambut melalui Program Tanggung Jawab Sosial Perusahaan: Analisis Pendekatan Penghidupan Berkelanjutan

4. Rendahnya daya tumpu terhadap bangunan keras,

5. Adanya lapisan pirit dan pasir di dasar gambut,

6. Tingkat keasaman tanah dan air yang tinggi karena mengandung senyawa organik, serta

7. Kandungan air yang sukar dikendalikan, yang berujung pada

8. Air jenuh pada gambut (menggenang di musim hujan dan kekeringan saat kemarau)

Kendala di atas pada gilirannya membuat ongkos budidaya pertanian relatif lebih mahal dan kurang produktif. Belum lagi, para petani harus dihantui cuaca buruk dan serangan hama. Kondisi lahan gambut yang sedemikian rentan meningkatkan risiko kegagalan panen yang membuat para petani lahan gambut sangat menderita (Najiyati et al., 2005:30-32).

Kerentanan lain yang hingga saat ini masih menjadi ancaman bagi komunitas petani lahan gambut adalah persoalan kesehatan. Tingginya tingkat keasaman air sungai juga menjadi salah satu penyebab berbagai masalah kesehatan seperti malaria, demam kuning (yellow fever), demam berdarah, filariasis dan encephalitia serta penyakit tropika dan subtropika yang berkaitan dengan lahan gambut lainnya (Adhani, 2016). Hal ini diperparah oleh luasnya lahan gambut yang membuat keterlintasan medan (terrain trafficability) dan keterjangkauan wilayah (area accessibility) di lahan gambut sangat rendah. Secara umum, hal ini berimbas pada rendahnya mobilitas penduduk dan sulitnya akses untuk mendapatkan pelayanan kesehatan (Notohadiprawiro, 2006).

\section{Mitigasi Kebencanaan Melalui Optimasi Modal} Sosial, Manusia dan Fisik

Salah satu kelompok masyarakat yang turut berperan aktif dalam upaya pemeliharan lingkungan khususnya terhadap bencana kebakaran hutan dan lahan adalah Masyarakat Peduli Api (MPA). Kelompok ini merupakan warga lokal yang bergabung secara sukarela maupun atas penunjukan dari pemerintah kelurahan. Sayangnya, upaya yang mereka lakukan selama ini kurang diapresiasi. Dalam pelaksanaannya, mereka bergerak sendiri-sendiri dan dengan menggunakan perlengkapan yang seadanya. Akibatnya, proses pemadaman kebakaran hutan dan lahan yang terjadi di Kelurahan Tanjung Palas terkadang membutuhkan waktu yang relatif lama. Hal ini diperparah dengan minimnya sumber air yang memang menjadi barang langka di lahan pertanian gambut, khususnya pada musim kemarau.

"Biasanya kita pakai alat seadanya saja, nggak pakai pelindung atau apa. Apa yang ada di rumah yaitu yang kita pakai. Susahnya kalau alatnya ada, tapi airnya tidak ada. Itu yang susah. Kita mau madamin api dari mana kalau airnya tidak ada. Sedangkan api itu sudah pasti jalan terus di bawah tanah. Meskipun apinya tidak terlihat, tapi lapisan tanah di bawah itu terbakar dan terus menyebar." (Robinson, Wawancara 02 April 2021).

Pada dasarnya, program DEWIGATRA berusaha untuk memitigasi masyarakat petani lahan gambut dari bencana kebakaran hutan dan lahan melalui tiga cara, yaitu reintegrasi Kelompok Masyarakat Peduli Api (MPA), peningkatan sarana dan prasarana tanggap kebencanaan, dan perubahan pola pertanian dengan menerapkan inovasi Drip Irrigation System. Adapun upaya-upaya tersebut dilakukan guna mendukung modal social, human, physical, serta natural masyarakat petani lahan gambut di Kelurahan Tanjung Palas. Dengan mengintegrasikan MPA yang selama ini terpecah dan bekerja secara sendiri-sendiri, proses pemadaman api yang dilakukan pada saat kebakaran dapat dilakukan dengan lebih cepat. Hal ini dikarenakan PT Pertamina RU II Dumai telah mengadakan serangkaian pelatihan mitigasi kebakaran hutan dan lahan, serta menunjang setiap prosesnya melalui pengadaan sarana dan prasarana pemadaman berupa mesin pompa, selang, dan coverall lengkap dengan embung di 15 titik rawan kebakaran, yang dapat digunakan setiap saat sebagai sumber air darurat bahkan saat musim kemarau sekalipun.

"Dulunya ya kalau ada kebakaran dengan alat yang seadanya itu aja. Nggak pakai apa-apa karena memang nggak punya. Itulah kenapa tugas ini sebenarnya berat. Karena selain bertanggung jawab atas lingkungan dan nyawa banyak orang, kami-kami inijuga bertanggung jawab terhadap keselamatan diri sendiri." (Tambunan, Wawancara 20 Mei 2021).

Dari pernyataan Tambunan, kegiatan pemadaman yang dilakukan MPA Tanjung Palas dilakukan dengan alat pelindung diri yang minim. 
Dalam konteks penghidupan berkelanjutan, hal tersebut merupakan aspek lain dari kerentanan pada bencana kebakaran hutan dan lahan. Tingginya risiko yang menghantui MPA tatkala melakukan aksi pemadaman membuat keluarga mereka dalam bahaya yang besar, terlebih mereka merupakan tulang punggung keluarga yang menghidupi istri dan beberapa anak yang tidak atau belum bekerja. Oleh karena itu, pengadaan alat pemadam, infrastruktur pendukung, hingga alat pelindung diri mampu mengeliminasi atau setidaknya meminimalisasi risiko dan kerentanan pada bencana kebakaran hutan dan lahan. Dalam upayanya itu, PT Pertamina RU II Dumai menggandeng beberapa stakeholder seperti Manggala Agni, Aksi Cepat Tanggap (ACT), dan Badan Penanggulangan Bencana Daerah (BPBD). Dengan begitu, kebakaran dapat ditangani dengan waktu yang lebih efektif dan efisien. Upaya ini merupakan prioritas agar dapat mencegah bencana menyebar pada kluster yang lebih luas.

Meskipun telah menunjukkan komitmen terhadap bencana kebakaran hutan melalui upaya preventif melalui program CSR, PT Pertamina RU II Dumai tidaklantas menutup mata terhadap kebakaran hutan dan lahan yang bisa terjadi kapan saja. Jika kebakaran lahan terjadi di lingkungan operasional perusahaan, maka PT Pertamina RU II Dumai turut berpartisipasi dalam melakukan pemadaman. Hal tersebut sebagai wujud komitmen perusahaan terhadap kelestarian alam dan lingkungan, sebagaimana disampaikan oleh Imam Rismanto selaku Unit Manager Community Relation \& CSR.

\section{Gambar 5}

Pelatihan Penggunaan Alat Pemadam Karhutla bersama Aksi Cepat Tanggap (ACT)

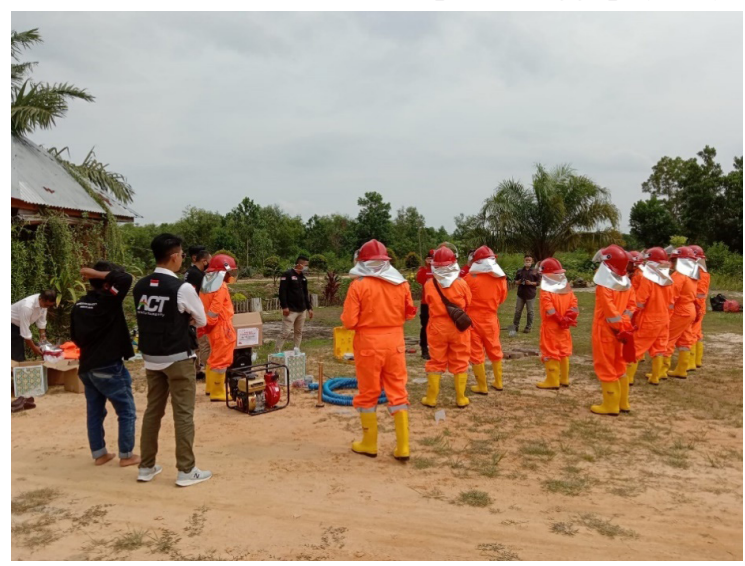

Sumber: Penulis, 2021
"Kalau memang ada kebakaran, biasanya kita selalu siap membantu pemadaman yang dilakukan di tingkat kelurahan. Selain mobil pemadam, kami juga tanggap dengan memberikan bahan-bakar berupa minyak untuk akomodasi serta konsumsi." (Imam Rismanto, Wawancara 10 Juni 2021).

Di luar tujuan tersebut, masyarakat ternyata memiliki inisiatif untuk mengembangkan embung yang telah dibuat sebagai budidaya ikan lele akar. Sehingga bantuan embung yang diberikan oleh PT. Pertamina RU II Dumai sebagai mitigasi bencana secara tidak langsung juga turut meningkatkan kesejahteraan melalui penambahan aspek penghidupan lain dan memberikan dampak ekonomi mencapai Rp3.600.000,- setiap panennya.

Peningkatan keterampilan dan infrastruktur pendukung pemadaman memang memberikan dampak yang cukup signifikan terhadap upaya pemadaman kebakaran hutan dan lahan di Kelurahan Tanjung Palas, akan tetapi tidak dengan bencana banjir. Oleh karena itu, melalui program yang sama, PT. Pertamina RU II Dumai juga mengajak masyarakat untuk mengubah sistem pertanian dengan membuat bedengan. Upaya ini terbukti dapat meminimalisasi kerusakan yang diakibatkan oleh bencana banjir pada lahan gambut, khususnya pada varietas tanaman hortikultura.

\section{Peningkatan Modal Alam dan Keuangan Melalui Program Pemberdayaan}

Salah satu permasalahan yang dihadapi oleh para petani dalam mengolah lahan gambut adalah karakteristik gambut yang kering dan kurang bisa menahan air. Memang jenis lahan ini tergolong subur dan kaya akan unsur hara. Akan tetapi, pengelolaannya membutuhkan cukup banyak air untuk menjaga lahan gambut tetap lembap, karena jenis lahan ini menyerap air dengan sangat cepat. Kesulitan pengolaan lahan pertamina pun dikeluhkan tidak hanya sekali oleh masyarakat.

"Memang agak susah kalau di sini. Mudah sekali terbakar, tapi kalau sudah hujan itu banjir bisa sampai pinggang. Apa lagi yang bisa dipanen kalau air sudah sampai pinggang? Nanas pun sudah terlanjur busuk tidak bisa dipanen." (Siti, Wawancara $7 \mathrm{Mei}$ 2021). 
M. Fatkhullah, Iwed Mulyani, Bambang Imawan - Strategi Pengembangan Masyarakat Petani Lahan Gambut melalui Program Tanggung Jawab Sosial Perusahaan: Analisis Pendekatan Penghidupan Berkelanjutan

Oleh karena itu, PT. Pertamina RU II Dumai berupaya untuk mengubah sistem pertanian dengan menghadirkan inovasi drip irrigation system. Metode ini memungkinkan lahan gambut yang kering menjadi basah dan lembab tanpa harus mengeluarkan biaya tambahan untuk pengairan. Dengan metode ini, para petani dapat menghemat sekitar 67.500 liter dengan nilai penghematan air yang mencapai Rp10.000.000,-. Sebagai hasilnya, tanah yang dulunya sulit diolah bisa menghasilkan 11 varietas tanaman hortikultura. Adapun enam jenis di antaranya merupakan produk organik. Dalam konteks penghidupan berkelanjutan, diversifikasi produk pertanian termasuk dalam aspek peningkatan modal alam karena upaya ini esensial untuk mengurangi risiko serangan hama, menjaga kesuburan tanah, serta mengurangi ketergantungan petani terhadap komoditas tertentu (Sumaryanto, 2009:93-108).

"Fokus kami ialah untuk merubah budaya bertani masyarakat yang selama ini kalau nggak menanam sawit, kopi, akasia, ya tumbuhan yang usia panennya lama menjadi pertanian hortikultur. Memang sebenarnya tidak ada masalah dengan jenis pertanian seperti itu, tapi kita tahu sendiri kan lahan gambut sangat rawan terbakar, jadi untuk meminimalisir hal tersebut kita promosikan pertanian hortikultur ini agar masyarakat lebih cepatdalam memanen hasil pertaniannya." (Kenny Bastian, Wawancara 15 Juni 2021).

Dari pernyataan Kenny Bastian selaku Community Development Officer, dengan mengalihkan komoditas tanaman dengan jangka panen yang lebih pendek, risiko kerugian karena kebakaran hutan dapat diminimalisasi. Selain itu, produksi varietas tanaman organik yang dihasilkan oleh petani mampu meningkatkan penghasilan karena memiliki nilai jual yang lebih tinggi di pasaran. Produk-produk pertanian yang dihasilkan pun tidak langsung dijual. Sebagian diolah oleh kelompok UMKM menjadi aneka makanan kering, sebagiannya lagi dijual di tingkat lokal dengan bekerja sama dengan masyarakat sekitar, swalayan lokal. Upaya lain untuk meningkatkan kesejahteraan petani adalah dengan berupaya menekan biaya produksi pertanian. Hal ini dilakukan dengan cara menerapkan sistem pertanian zero waste, di mana sampah hasil pertanian akan diolah kembali menjadi pupuk. Dengan melakukan optimasi melalui penekanan biaya produksi dan peningkatan nilai jual, produk pertanian Paman Jaya Mandiri mampu mencapai 3 ton per panen dengan nilai peningkatan pendapatan sebanyak Rp5.000.000,- per orang.

\section{Gambar 6 \\ Penerapan Drip Irrigation System pada Pertanian Lahan Gambut}

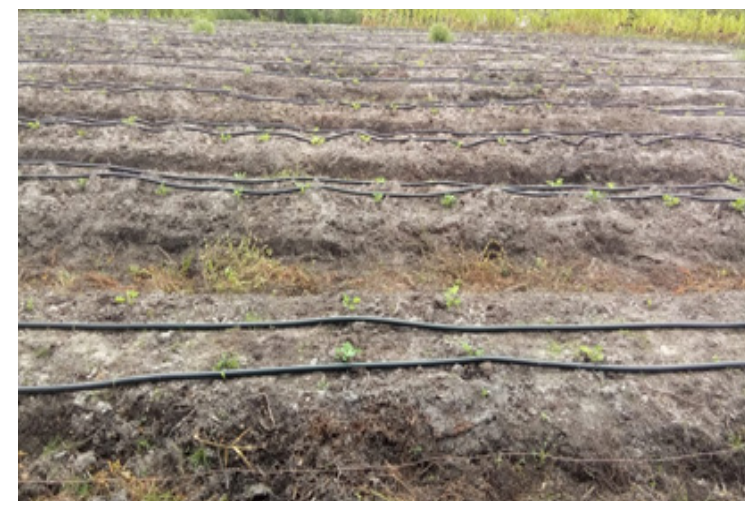

Sumber: Penulis, 2021

Fokus dalam pendekatan penghidupan berkelanjutan adalah meningkatkan tiap-tiap modal penghidupan secara berkesinambungan agar kehidupan masyarakat dapat berjalan dengan seimbang. Peningkatan modal alam dan pendapatan tanpa dibarengi dengan kemampuan pengelolaan yang baik (human capital) dikhawatirkan dapat membuat aset yang diakumulasikan perlahan berkurang atau bahkan hilang. Oleh sebab itu, PT. Pertamina RU II Dumai juga mengadakan rangkaian pelatihan pembukuan. Tidak hanya meningkatkan kapasitas dalam mengelola keuangan, pembukuan yang baik dapat menjadi modal utama bagi masyarakat untuk bisa mendapatkan akses pada sumber-sumber keuangan lain seperti pinjaman bank (financial capital).

Di lain pihak, Program Kemitraan dan Bina Lingkungan (PKBL) yang secara aktif dipromosikan oleh PT. Pertamina RU II Dumai juga turut memberikan sumbangsih bagi akses finansial kepada masyarakat secara umum, khususnya masyarakat petani lahan gambut sebagai mitra binaan. Program ini merupakan salah satu upaya untuk mempermudah akses pinjaman sosial dengan bunga rendah. Adapun keuntungan dari bunga yang didapatkan tidak 
akan dihitung sebagai keuntungan perusahaan, melainkan dikembalikan kepada mitra dalam bentuk pameran usaha, pop-up market di mall, UMKM Center dan Business Matching, serta upaya lain untuk mendorong. Perluasan pemasaran produk mitra binaan agar mereka dapat membuka pasar dengan jangkauan yang lebih luas.

\section{Diskusi}

Kerentanan, potensi penghidupan, masalah akses dan tantangan, transformasi struktur dan proses, serta optimalisasi penghidupan berkelanjutan yang diakomodasi melalui program CSR PT. Pertamina RU II Dumai dapat dilihat pada tabel 2. Pada awalnya, program ini hanya berfokus pada penguatan kelembagaan MPA untuk mengatasi bencana kebakaran hutan dan lahan. Akan tetapi, kelompok ini bergerak secara parsial dan baru akan beraksi ketika kebakaran terjadi. Akibatnya, proses pemadaman cenderung lama dan kurang efektif. Bahkan, kelompok ini mengalami kemunduran karena minimnya apresiasi, baik dari pemerintah, maupun dari masyarakat itu sendiri. Satu-satunya hal yang membuat mereka bertahan adalah kenyataan bahwa mereka masih memiliki rumah, ladang, dan penghidupan tempat mereka bergantung. Oleh karena itu, dibutuhkan suatu intervensi yang dapat mengikat dan meningkatkan kinerja tiap anggota tanpa membuat mereka merasa tergantung dengan adanya program tersebut. Dalam hal ini, pemberdayaan masyarakat melalui sektor pertanian menjadi alternatif jawaban yang cukup menjanjikan. Selain dapat memberikan apresiasi dalam bentuk peningkatan kondisi ekonomi, program ini juga dapat menjadi proyek untuk menjaga kelestarian ekosistem gambut dengan pengelolaan yang mengutamakan aspek keberlanjutan. Harapannya, Kelompok Tani Paman Jaya Mandiri dapat menjadi percontohan bagi komunitas petani lain untuk mengolah lahan gambut dengan mengutamakan aspek keberlanjutan.

Pada tahap awal program ini dilaksanakan, karakteristik permukaan gambut yang kering membuat varietas produk pertanian menjadi terbatas, sementara biaya untuk pengelolaannya menjadi lebih mahal. Oleh karena itu, inovasi dibutuhkan baik untuk menekan biaya produksi, maupun mengoptimalkan hasil pertanian. Dalam hal ini, program DEWIGATRA mengakomodasi kebutuhan tersebut melalui penerapan drip irrigation system untuk mengatasi kondisi lahan yang kering, serta penerapan zero waste dengan memanfaatkan limbah pertanian menjadi pupuk organik. Dengan begitu, biaya pertanian dapat ditekan. Dalam kaitannya dengan pengoptimalan hasil pertanian, PT. Pertamina RU II Dumai juga mendorong kelompok petani untuk mengolah produk mereka menjadi aneka kripik dengan nilai jual yang lebih tinggi dan masa simpan yang lebih panjang.

Meskipun berhasil menekan biaya produksi dan mengoptimalkan pendapatan hasil pertanian, namun dimensi risiko tidak bisa dieliminasi sepenuhnya. Ekosistem gambut yang terlanjur rusak membuat fleksibilitas dalam menampung air menjadi sangat buruk. Meskipun jumlah kebakaran hutan dan lahan dapat diminimalisasi pada musim kemarau, namun nyatanya kegagalan panen tetap tidak bisa dihindari karena kebanjiran pada musim hujan. Menanggapi permasalahan tersebut, PT. Pertamina RU II Dumai mengupayakan penerapan bedengan pada lahan pertanian masyarakat untuk mencegah tergenangnya produk pertanian. Untuk mengoptimalkan aset penghidupan yang telah dioptimalisasi, PT. Pertamina RU II Dumai juga berupaya sebaik mungkin untuk menjaga sumber finansial dengan melakukan pelatihan pembukuan.

Selain dari upaya-upaya tersebut, PT. Pertamina RU II Dumai juga mendorong masyarakat untuk mengembangkan usahanya melalui Program Kemitraan dan Bina Lingkungan sebagai perwujudan ketaatan terhadap Pasal 74 Undang-Undang No. 40 Tahun 2007 tentang Perseroan Terbatas. Dalam konteks penghidupan berkelanjutan, upaya ini merupakan salah satu bentuk pemberian akses terhadap sumber keuangan baik secara langsung maupun tidak langsung. Dalam konteks ketaatan terhadap undang-undang terkait, dalam hal ini Pertamina RU II Dumai telah berada selangkah lebih maju karena menempatkan Program Kemitraan dan Bina Lingkungan (PKBL) sebagai supporting program dalam rangka menunjang program utama, yaitu Desa Wisata Gambut Sejahtera (DEWIGATRA).

Secara keseluruhan, baik dari segi transformasi struktur, proses, mitigasi aspek kerentanan, hingga upaya peningkatan aset penghidupan, program DEWIGATRA lebih berfokus pada upaya peningkatan kesejahteraan 
Tabel 2.

Optimasi Penghidupan Berkelanjutan pada Petani Lahan Gambut melalui Program DEWIGATRA

\begin{tabular}{|c|c|c|c|c|c|}
\hline $\begin{array}{l}\text { Kerentanan } \\
\text { Masyarakat }\end{array}$ & $\begin{array}{c}\text { Potensi } \\
\text { Penghidupan } \\
\text { Berkelanjutan } \\
\end{array}$ & $\begin{array}{l}\text { Masalah Akses \& } \\
\text { Tantangan }\end{array}$ & $\begin{array}{c}\text { Transformasi Struktur } \\
\text { \& Proses }\end{array}$ & $\begin{array}{c}\text { Outcome } \\
\text { Penghidupan }\end{array}$ & \\
\hline \multirow{4}{*}{$\begin{array}{l}\text { Kebakaran } \\
\text { Hutan dan } \\
\text { Lahan }\end{array}$} & \multirow{3}{*}{$\begin{array}{l}\text { Adanya } \\
\text { kelembagaan } \\
\text { MPA yang } \\
\text { bergerak } \\
\text { di bidang } \\
\text { penanganan } \\
\text { kebakaran } \\
\text { hutan dan } \\
\text { lahan }\end{array}$} & $\begin{array}{l}\text { Kelembagaan yang } \\
\text { tidak responsif } \\
\text { dan masih bekerja } \\
\text { sendiri-sendiri }\end{array}$ & $\begin{array}{l}\text { Reintegrasi dengan } \\
\text { menguatkan kelompok } \\
\text { Masyarakat Peduli Api }\end{array}$ & $\begin{array}{l}\text { Kelompok MPA kembali } \\
\text { Aktif dan terintegrasi }\end{array}$ & Sosial \\
\hline & & $\begin{array}{l}\text { Minimnya sarana } \\
\text { \& prasarana, serta } \\
\text { Tingginya risiko } \\
\text { dalam melakukan } \\
\text { upaya pemadaman } \\
\text { api }\end{array}$ & $\begin{array}{l}\text { Memberikan bekal } \\
\text { dan kemampuan } \\
\text { pemadaman, serta } \\
\text { sarana dan prasarana } \\
\text { pendukung untuk } \\
\text { meminimalisasi risiko }\end{array}$ & $\begin{array}{l}\text { Menurunkan risiko } \\
\text { upaya pemadaman } \\
\text { melalui peningkatan } \\
\text { kapasitas serta kualitas } \\
\text { sarana dan prasarana }\end{array}$ & $\begin{array}{l}\text { Manusia } \\
\text { Fisik }\end{array}$ \\
\hline & & $\begin{array}{l}\text { Belum adanya } \\
\text { apresiasi terhadap } \\
\text { kelompok MPA }\end{array}$ & $\begin{array}{l}\text { Memberikan apresiasi } \\
\text { melalui program } \\
\text { pemberdayaan melalui } \\
\text { sektor pertanian }\end{array}$ & $\begin{array}{l}\text { Meningkatkan } \\
\text { kesejahteraan kelompok } \\
\text { MPA, sehingga } \\
\text { kelembagaan dalam } \\
\text { MPA dapat bertahan }\end{array}$ & $\begin{array}{c}\text { Sosial } \\
\text { Manusia }\end{array}$ \\
\hline & $\begin{array}{l}\text { Banyaknya } \\
\text { lahan yang } \\
\text { belum } \\
\text { termanfaatkan }\end{array}$ & $\begin{array}{l}\text { Sulitnya } \\
\text { mendapatkan } \\
\text { sumber air ketika } \\
\text { kebakaran terjadi } \\
\text { pada saat musim } \\
\text { kemarau }\end{array}$ & $\begin{array}{l}\text { Menyediakan embung } \\
\text { di } 15 \text { titik rawan } \\
\text { kebakaran sebagai } \\
\text { penampung dan } \\
\text { penyedia sumber air }\end{array}$ & $\begin{array}{l}\text { Memudahkan upaya } \\
\text { pemadaman melalui } \\
\text { penyediaan sumber } \\
\text { air di } 15 \text { titik rawan } \\
\text { kebakaran }\end{array}$ & $\begin{array}{l}\text { Fisik } \\
\text { Alam }\end{array}$ \\
\hline \multirow{5}{*}{$\begin{array}{l}\text { Kemiskinan } \\
\text { pada } \\
\text { Masyarakat } \\
\text { Petani } \\
\text { di Lahan } \\
\text { Gambut }\end{array}$} & \multirow{2}{*}{$\begin{array}{l}\text { Terdapat } \\
\text { lahan seluas } \\
5 \text { hektar } \\
\text { yang belum } \\
\text { dimanfaatkan }\end{array}$} & $\begin{array}{l}\text { Ekosistem gambut } \\
\text { yang kering } \\
\text { membuat pilihan } \\
\text { varietas pertanian } \\
\text { menjadi terbatas }\end{array}$ & $\begin{array}{l}\text { Penerapan drip } \\
\text { irrigation system } \\
\text { dalam pertanian untuk } \\
\text { menjaga kelembapan } \\
\text { permukaan tanah }\end{array}$ & $\begin{array}{l}\text { Membuat } 11 \text { varietas } \\
\text { tanaman hortikultura } \\
\text { dapat ditanam di lahan } \\
\text { gambut } \\
\text { Menjaga kelembapan } \\
\text { tanah sehingga } \\
\text { meminimalisasi potensi } \\
\text { karhutla }\end{array}$ & Alam \\
\hline & & $\begin{array}{l}\text { Biaya pertanian di } \\
\text { lahan gambut yang } \\
\text { relatif lebih mahal } \\
\text { dari pertanian pada } \\
\text { jenis lahan lainnya }\end{array}$ & $\begin{array}{l}\text { Menerapkan sistem } \\
\text { zero waste dengan } \\
\text { memanfaatkan limbah } \\
\text { domestik dan hasil } \\
\text { pertanian sebagai } \\
\text { pupuk organic }\end{array}$ & $\begin{array}{l}\text { Menurunkan biaya } \\
\text { produksi pertanian } \\
\text { sebanyak } 20 \% \\
\text { dengan mengurangi } \\
\text { penggunaan pupuk } \\
\text { kimia }\end{array}$ & $\begin{array}{l}\text { Finansial } \\
\text { Alam }\end{array}$ \\
\hline & \multirow{2}{*}{$\begin{array}{l}\text { Melimpahnya } \\
\text { hasil } \\
\text { pertanian }\end{array}$} & \multirow{2}{*}{$\begin{array}{l}\text { Minimnya jaringan } \\
\text { pemasaran untuk } \\
\text { produk mentah } \\
\text { pertanian }\end{array}$} & $\begin{array}{l}\text { Membuat warung } \\
\text { pertanian untuk } \\
\text { memudahkan } \\
\text { pemasaran produk }\end{array}$ & $\begin{array}{l}\text { Terserapnya produk } \\
\text { para petani pada tingkat } \\
\text { lokal }\end{array}$ & Finansial \\
\hline & & & $\begin{array}{l}\text { Mengoptimalkan } \\
\text { pendapatan melalui } \\
\text { pengolahan hasil } \\
\text { pertanian }\end{array}$ & $\begin{array}{l}\text { Terdapat produk UMKM } \\
\text { Sehingga memberikan } \\
\text { penghasilan tambahan }\end{array}$ & Finansial \\
\hline & $\begin{array}{l}\text { Terdapat } \\
\text { golongan } \\
\text { pemuda dalam } \\
\text { kelembagaan }\end{array}$ & $\begin{array}{l}\text { Keuangan dalam } \\
\text { kelembagaan yang } \\
\text { belum matang } \\
\text { dan sulitnya } \\
\text { mendapatkan akses } \\
\text { pinjaman untuk } \\
\text { pengembangan } \\
\text { usaha }\end{array}$ & $\begin{array}{l}\text { Pelatihan pembukuan } \\
\text { untuk meningkatkan } \\
\text { kemampuan dalam } \\
\text { mengelola keuangan, } \\
\text { serta memperkenalkan } \\
\text { program Kemitraan } \\
\text { sebagai akses sumber } \\
\text { keuangan }\end{array}$ & $\begin{array}{l}\text { Anggota kelompok } \\
\text { tani dapat mengelola } \\
\text { keuangan, melakukan } \\
\text { pembukuan dan } \\
\text { mengajukan pinjaman }\end{array}$ & Finansial \\
\hline
\end{tabular}




\begin{tabular}{|c|c|c|c|c|c|}
\hline $\begin{array}{l}\text { Banjir dan } \\
\text { Kegagalan } \\
\text { Panen }\end{array}$ & $\begin{array}{l}\text { Terdapat } \\
\text { kelompok } \\
\text { petani }\end{array}$ & $\begin{array}{l}\text { Ekosistem } \\
\text { gambut yang } \\
\text { rusak kehilangan } \\
\text { fleksibilitas dalam } \\
\text { menyimpan air }\end{array}$ & $\begin{array}{l}\text { Menerapkan bedengan } \\
\text { di lahan pertanian } \\
\text { gambut, sehingga } \\
\text { produk pertanian } \\
\text { dapat bertahan dan air } \\
\text { dialirkan ke parit }\end{array}$ & $\begin{array}{l}\text { Meminimalisir } \\
\text { kegagalan panen karena } \\
\text { bencana banjir di } \\
\text { musim penghujan pada } \\
\text { lahan pertanian gambut }\end{array}$ & Finansial \\
\hline $\begin{array}{l}\text { Kesehatan } \\
\text { Masyarakat }\end{array}$ & $\begin{array}{l}\text { Adanya } \\
\text { infrastruktur } \\
\text { berupa jalan }\end{array}$ & $\begin{array}{l}\text { Kondisi jalan yang } \\
\text { rusak dan sulit } \\
\text { dilalui saat dalam } \\
\text { kondisi yang } \\
\text { tergenang }\end{array}$ & $\begin{array}{l}\text { Pembangunan } \\
\text { infrastruktur berupa } \\
\text { akses jalan untuk } \\
\text { memudahkan } \\
\text { mobilitas masyarakat } \\
\text { saat keadaan darurat }\end{array}$ & $\begin{array}{l}\text { Meningkatnya mobilitas } \\
\text { masyarakat, baik dalam } \\
\text { upaya mitigasi bencana } \\
\text { epidemi maupun } \\
\text { karhutla }\end{array}$ & Fisik \\
\hline
\end{tabular}

Sumber: Penulis, 2021

melalui peningkatan perekonomian masyarakat. Sayangnya, perubahan sistem pertanian dengan mengutamakan komoditas pertanian hortikultura belum menjawab permasalahan utama terkait penyebab terbesar kebakaran hutan di lahan gambut, yaitu pembukaan lahan dengan cara dibakar. Hal ini dikarenakan pembukaan lahan tidak hanya diperuntukkan untuk upaya pertanian, namun juga alih guna lahan menjadi kawasan industri dan perumahan. Selain itu, luas lahan yang digarap oleh Kelompok Tani Paman Jaya Mandiri juga dapat dikatakan relatif kecil, yaitu hanya seluas 5 ha. Artinya, jika dilihat secara makro, program yang mengampanyekan perubahan sistem pertanian ini hanya menyentuh $0,1 \%$ dari total 45,816 ha zona lahan gambut budidaya di Kota Dumai. Selain kebakaran hutan dan lahan, aspek kerentanan lain yang belum terlalu diperhatikan adalah Kesehatan. Padahal, masih banyak risiko penyakit seperti seperti malaria, demam kuning (yellow fever), demam berdarah, filariasis dan encephalitia serta penyakit tropika dan subtropika yang mengintai masyarakat petani di lahan gambut.

\section{Kesimpulan}

Pengembangan masyarakat petani di lahan gambut melalui program DEWIGATRA berfokus pada dua upaya. Pertama, mitigasi kebencanaan melalui peningkatan kualitas modal social, human dan physical. Hal ini diwujudkan dengan melakukan reintegrasi kelompok Masyarakat Peduli Api (MPA), pelaksanaan pelatihan mitigasi bencana karhutla, serta pengadaan sarana dan prasarana berupa alat pemadam dan infrastruktur dalam bentuk embung yang tersebar di 15 zona merah karhutla. Dengan dukungan sarana dan prasarana serta pengetahuan yang memadai terkait pemadaman kebakaran, MPA akan lebih siap dalam menghadapi bencana kebakaran selanjutnya. Selain itu dengan menjaga ekosistem gambut, maka kelompok petani turut berperan aktif dalam melestarikan flora dan fauna, serta perubahan iklim global.

Kedua, pengembangan modal natural dan financial melalui program pemberdayaan masyarakat. Upaya ini dilakukan dengan mengubah sistem pertanian dengan menghadirkan inovasi drip irrigation system. Penerapan sistem pertanian hortikultura dapat meminimalisir potensi kerugian dibandingkan jika petani menanam komoditas tahunan seperti sawit dan kopi. Tanah yang dulunya kering dan sulit diolah kini bisa menghasilkan 11 varietas tanaman hortikultura, yang mana 6 jenis diantaranya merupakan produk pertanian organik yang memiliki nilai ekonomi yang tinggi. Dari hasil pertanian tersebut, kelompok binaan PT. Pertamina RU II Dumai dapat mengumpulkan 3 ton hasil pertanian dengan pendapatan mencapai Rp5.000.000,- per orang. Selain berdampak pada peningkatan penghasilan, penerapan drip irrigation system juga memberikan sumbangsih pada penghematan penggunaan air untuk usaha pertanian sebanyak 67.500 liter dengan nilai penghematan setara Rp10.000.000,-. Sayangnya, belum terlihat adanya upaya progresif baik untuk mencegah maupun mengatasi risiko kesehatan yang justru menjadi ancaman besar bagi masyarakat yang tinggal di lahan gambut.

\section{Rekomendasi}

Dengan mempertimbangkan aspek kerentanan pada dimensi kesehatan yang kurang menjadi prioritas pada Program Desa 
M. Fatkhullah, Iwed Mulyani, Bambang Imawan - Strategi Pengembangan Masyarakat Petani Lahan Gambut melalui Program Tanggung Jawab Sosial Perusahaan: Analisis Pendekatan Penghidupan Berkelanjutan

Wisata Gambut Sejahtera (DEWIGATRA), maka rekomendasi pengembangan masyarakat petani pada lahan gambut di Kelurahan Tanjung Palas lebih menitikberatkan pada mitigasi bencana berupa epidemi dan masalah kesehatan lainnya. Hal tersebut dapat dilakukan dengan menambah varietas produk berupa tanaman obat keluarga, sosialisasi Perilaku Hidup Bersih dan Sehat (PHBS), serta perbaikan infrastruktur dan akses pada fasilitas kesehatan. Guna meningkatkan skala dampak dan penerima manfaat program, perlu adanya komitmen yang terlembagakan dan mengikat para petani penerima manfaat langsung untuk secara terus menerus menyosialisasikan dan menyebarluaskan pengetahuan yang telah didapat melalui program DEWIGATRA, sehingga keberlanjutan dampak program dapat lebih dipastikan.

\section{Referensi}

Adhani, R. (2016). Pengembangan Model Pemberdayaan Masyarakat Lahan Basah untuk Membudayakan Gosok Gigi dengan Air yang Memenuhi Persyaratan Kesehatan dalam Penanggulangan Tingginya Indeks Karises Gigi di Kalimantan Selatan. Banjarmasin: Project Report. Lembaga Penelitian Universitas Lambung Mangkurat.

Badan Restorasi Gambut. (2017). Peta Indikatif Prioritas Restorasi Provinsi Riau. Retrieved from https://brg.go.id/wp-content/ uploads/2017/03/BRG_Peta-RestorasiRiau.pdf

Burrows, L. (2016, September 19). Smoke from 2015 Indonesian fires may have caused 100,000 premature deaths. Retrieved from Harvard John A. Paulson School of Engineering and Applied Sciences: https:// www.seas.harvard.edu/news/2016/09/ smoke-2015-indonesian-fires-may-havecaused-100000-premature-deaths

Chambers, R., \& Conway, G. (1992). Sustainable rural livelihoods: Practical concepts for the 21st century. Brighton: IDS Discussion Paper.

Christophersen, T. (2016, July 31). Peat Fires Stoke Global Warming. Retrieved from UNREDD Programme: https://www.un-redd. org/post/2016/07/31/Peat-fires-stokeglobal-warming

Comeau, L.-P., Hergoualc'h, K., Smith, J. U., \& Verchot, L. (2013). Conversion of intact peat swamp forest to oil palm plantation. Bogor: Center for International Forestry Research.
De Stagé, R., Holloway, A., Mullins, D., \& Nchabaleng, L. a. (2002). Learning about livelihoods: Insights from Southern Africa. Oxford: Oxfam Publishing.

Dugan, P. J. (1990). Wetland Conservation : a Review of Current Issues and Required Action. Gland, Switzerland: World Conservation Union (IUCN).

Giesen, W. (1991). Berbak Wildlife Reserve, Jambi, Sumatra. Final Draft Survey Report. Bogor: PHPA/AWB Sumatra Wetland Project Report No. 13.

Hergoualc'h, K., Carmenta, R., Atmadja, S., Martius, C., Murdiyarso, D., \& Purnomo, H. (2018). Managing peatlands in Indonesia: Challenges and opportunities for local and global communities. Bogor: Center for International Forestry Research (CIFOR).

Huijnen, V., Wooster, M. J., Kaiser, J. W., Gaveau, D. L., Flemming, J., Parrington, M., ... Weele, M. v. (2016). Fire carbon emissions over maritime southeast Asia in 2015 largest since 1997. Scientific Reports, pp. 1-8.

Kolka, R. K., Murdiyarso, D., Kauffman, J. B., \& Birdsey, R. A. (2016). Tropical wetlands, climate, and land-use change: adaptation and mitigation opportunities. Wetlands Ecol Manage, pp. 107-122.

Kollmair, M. \&. (2002). The Sustainable Livelihood Approach. Input Paper for the Integrated Training Course of NCCR North-South. University of Zurich: Development Study Group.

Kurnia, M. (2014, November 12). Plasma Nutfah. Retrieved from Dinas Pertanian Pemerintah Kabupaten Palembang: https://distan. bulelengkab.go.id/informasi/detail/artikel/ plasma-nutfah-58

Las, I., Sarwani, M., Mulyani, A., \& Saragih, M. F. (2012). Dilema dan Rasionalisasi Kebijakan Pemanfaatan Lahan Gambut untuk Areal Pertanian. In E. Husen, M. Anda, M. Noor, M. H.S., Maswar, A. Fahmi, \& Y. Sulaeman, Pengelolaan Lahan Gambut Berkelanjutan (pp. 17-28). Bogor: Badan Penelitian dan Pengembangan Pertanian.

Moeloeng, L. J. (2010). Meotde Penelitian Kualitatif. Bandung: Rosda.

Najiyati, S., Asmana, A., \& Suryadiputra, I. N. (2005). Pemberdayaan Masyarakat Di Lahan Gambut. Bogor: Wetlands Internasional.

Notohadiprawiro, T. (2006). Etika Pengembangan Lahan Gambut untuk Pertanian Tanaman 
Pangan. Repro: Ilmu Tanah Universitas Gadjah Mada, pp. 1-11.

Ramsay, D. (2016, June 28). On land and in space, understanding the impacts of fires. Retrieved from Forests News: https://forestsnews. cifor.org/42098/on-land-and-in-spaceunderstanding-the-impacts-of-fires?fnl=en

Ritung, S., Wahyunto, Nugroho, K., Sukarman, Hikmatullah, uparto, \& afakresnanto, C. (2011). Peta Lahan Gambut Indonesia Skala 1:250.000 (Indonesian peatland map at the scale 1:250,000). Bogor: Indonesian Center for Agricultural Land Resources Research and Development.

Strack, M. (2008). Peatlands and Climate Change. Saarijärvi: International Peat Society.
Sumaryanto. (2009). Diversifikasi Sebagai Salah Satu Pilar Ketahanan Pangan. Forum Penelitian Agro Ekonomi, 27(2), pp. 93-108. Sutaryo, D., \& Suryadiputra, I. N. (2006). Strategi dan Rencana Tindak Nasional Pengelolaan Lahan Gambut Berkelanjutan. Jakarta: Departemen Dalam Negeri.

Wibisono, I. T., Siboro, L., \& Suryadiputra, I. N. (2004). Keanekaragaman Jenis Tumbuhan di Hutan Rawa Gambut. Bogor: Leaflet Seri Pengelolaan Hutan dan Lahan Gambut. Kerjasama Wetlands International Programme, dan Wildlife habitat Canada.

Zulkarnaini, \& Lubis, Z. E. (2018). Pemberdayaan Masyarakat dalam Pemanfaatan Ekosistem Rawa Gambut Secara Berkelanjutan. Jurnal Kebijakan Publik, 9(2), pp. 61-124. 